\title{
Anti-Counterfeiting Trade Agreement
}

\author{
Submission to the Joint Standing Committee on Treaties \\ From \\ Dr Hazel V J Moir \\ Adjunct Fellow, Centre for Policy Innovation, ANU \\ (hazel.moir@anu.edu.au)
}

\section{Conclusions / overview}

The Anti-Counterfeiting Trade Agreement (ACTA) should be rejected.

The evidence for there being a significant problem in counterfeit trademarks or unauthorised copies is weak. The OECD estimates that less than $2 \%$ of global trade is affected. In Australia only $0.01 \%$ of imports are seized counterfeit goods.

Some of our major trading parties strongly object to these matters being handled outside the normal forums (the WTO and WIPO).

ACTA is very poorly drafted, with a wide range of expansionary, ambit and unclear terms. Despite the objective being to deal with counterfeit trademarks and unauthorised copyright use, the treaty constantly refers to "intellectual property". Further there is frequent use of the expansionary term "at least". The treaty also uses inappropriate language, adopting the pejorative term "pirate" instead of the more appropriate "unauthorised". At a minimum the treaty needs to be redrafted to use clear, precise and unloaded language.

A wide range of remedies are already available (the NIA says nothing will change in Australia as a result of this treaty). ACTA proposes even further "remedies" including potential destruction of property owned by third parties, who may be entirely ignorant of the use of the property to produce infringing goods. At least one of these proposed forms of compensation is economic nonsense. There is no evidence in the NIA or in the OECD study on which the NIA draws that full consideration has been given to the very different nature of the various markets involved. Without such an understanding remedies can easily be disproportionate.

Innocent parties may be affected by ACTA. At one "consultation" representatives of shippers and freight forwarders raised significant and legitimate concerns about additional costs that would be imposed on them. A full cost benefit analysis is needed identifying all the parties affected, whether they will benefit or lose, and whether they are domestic or overseas parties. Full consideration should also be given to consumer interests.

These factors add to a bottom line where there is no clear and significant net economic gain to Australia. Indeed the ACTA treaty appears to be a sledgehammer in search of a very small nut. It does not meet basic drafting standards. ACTA therefore contravenes the principles of the current government's trade policy. ${ }^{1}$

\footnotetext{
${ }^{1}$ Gillard Government Trade Policy Statement, April 2011, available at http://www.dfat.gov.au/publications/trade/trading-our-way-to-more-jobs-and-prosperity.pdf
} 


\section{Introduction}

This submission takes an economic policy perspective to assessing ACTA. It is assumed that the objective of any trade treaty is to maximise Australian economic well-being.

I begin by assessing the evidence on the extent of the alleged problem of counterfeit trademarks and unauthorised use of copyright (Section 2.1). When considering possible remedies to infringement of trademarks, patents or any other legislated monopoly privilege it is also important to understand the nature of the markets and the extent to which they are competitive. Markets for counterfeit trademarks and unauthorised copies are quite different (see Section 2.2).

The submission then considers whether the proposals in ACTA are proportionate to what the data suggest is a rather small problem (of the order of $2 \%$ of world trade and a mere $0.01 \%$ of Australian consumer goods imports for traded physical counterfeits). Concerns raised are the expansionary language ("intellectual property", "at least"), the wide range of remedies available to "rights-holders", the economic nonsense of at least one of the proposed remedies. There are also issues about the apparently unlimited scope of ACTA (commercial scale is not defined). Questions are also raised as to whether it is appropriate to use public resources to enforce private commercial privileges (Section 3).

The submission ends by looking briefly at three disparate issues. Firstly it asks why Australia would want to agree to yet another multilateral treaty on "intellectual property" given the Productivity Commission's (PC) comments on this issue and the Government's positive response to the Commission's recommendations (Section 4.1). It then addresses one major issue raised by the constant use of the term "intellectual property" in what should have been drafted as a treaty on trademarks and copyright. This issue is "counterfeit" patented goods (Section 4.2). Thirdly some issues related to innocent third parties, primarily shippers and freight forwarders are raised (Section 4.3).

There are two short appendices, the first considers some more detailed issues in measuring the counterfeit goods markets and presents further data from the OECD report and from the United States Government Accountability Office (GAO). The second discusses what appears to be a substantial "pro-intellectual property" bias in Australia's trade negotiations despite the substantial evidence that this is not in Australia's interests.

\section{What is the extent of the problem?}

It is not possible to comment sensibly on ACTA without first reviewing the extent of the alleged problem with respect to counterfeit trademarks and unauthorised use of copyright. In the next section the evidence on the size of the alleged problem is reviewed. An equally important issue in assessing ACTA is the nature of the quite different markets in various forms of unauthorised use of products which claim "intellectual property" monopolies. These markets differ considerably depending on whether it is a trademark, a copyright or a patent which is being claimed by the "rights-holder" alleging infringement. It is essential to understand these different markets if one is to properly assess whether the extensive "remedies" proposed in ACTA are proportionate and this matter is discussed in Section 1.2. 


\subsection{Evidence presented by DFAT}

The National Interest Analysis (NIA) ${ }^{2}$ cites a major OECD study as indicating that international trade in "counterfeit and pirated [sic] materials" is growing and that the global value of this in 2007 was $\mathrm{A} \$ 250$ billion. This is not actually correct: the OECD update states that:

"counterfeit and pirated goods in international trade grew steadily over the period 2000

- 2007 and could amount to up to USD 250 billion in 2007 ... The share of counterfeit and pirated [sic] goods in world trade is also estimated to have increased from $1.85 \%$ in 2000 to $1.95 \%$ in $2007 . "$

(OECD 2009: 1, emphasis added)

During the period 2000 to 2007 world trade more than doubled. The OECD estimates a maximum of less than $2 \%$ of world trade being counterfeit goods are based on a survey of 70 out of 169 customs organisations which provided estimates of seized counterfeit goods for any part of the seven-year period 1999-2005. These estimates were used to generate proportions of exported goods which are counterfeit, and to estimate the proportion of traded goods of different types which are counterfeit. This generates a product-country propensity for counterfeit goods which can then be applied to international trade statistics. Any change in estimated counterfeit goods is therefore entirely attributable to increased volumes and values of international trade in particular product lines and from particular countries and not to any changed propensity for counterfeit goods. The growth in the proportion of international trade estimated to be counterfeit goods is therefore due to above average growth in trade in the types of goods and/or exports from countries most likely to generate counterfeit goods. In presenting its 2007 update the OECD advises that "[f]urther assessments of the share of counterfeiting and piracy in international trade would therefore require a new detailed assessment of customs data on seizures" (OECD 2009: 2).

In respect of counterfeit goods in Australia, the OECD report shows that the range of counterfeit products has not changed over the past five years (OECD 2008: 70). The NIA advises that seized alleged counterfeit products were $\mathrm{A} \$ 26 \mathrm{~m}$ in $2009-10$. They do not put this figure in context. In 2009-10 the value of merchandise imports was A $\$ 258,655 \mathrm{~m}$ (or A $\$ 205,217 \mathrm{~m}$ for imports of consumption goods). Using either of these measures as a base seized alleged counterfeit products are only $0.01 \%$ of Australian imports. ${ }^{3}$

These figures refer to trade in physical products. The OECD has done a separate study on unauthorised copies of digital material, but this has no estimates of the volume or value of this trade. For the US economy, the Government Accountability Office (GAO) indicates that, in the absence of reliable data, most estimates are based on assumptions (see Appendix 1). Industry sources, using very questionable assumptions, estimate substantial losses (e.g. 20\% for software). The few available academic studies show that losses are much more modest (e.g. less than $6 \%$ for music). Indeed one study of music downloading showed that this increased consumer welfare, releasing income for expenditure on other goods and services (Rob and Waldfogel 2006). The GAO cites one expert as considering that the main impact of

\footnotetext{
${ }^{2}$ The NIA does not give an author. From the content I have assumed it was prepared by DFAT. The DFAT website on ACTA refers to the NIA but does not disclose its authorship (http://www.dfat.gov.au/trade/acta/).

${ }^{3}$ The $\$ 26 \mathrm{~m}$ alleged counterfeit goods seized is from para 10 of the NIA. The value of merchandise imports during 2009-10 was calculated from ABS 5368.0 - International Trade in Goods and Services, Australia, Nov 2011, using the download facility to obtain a time series for total goods imports. Total goods imports for 200910 were $\$ 258,655 \mathrm{~m}$. If only consumption goods are included the value was $\$ 205,217$ but the proportion of alleged counterfeit goods seized remains constant at $0.01 \%$.
} 
counterfeiting is a redistribution of income not any overall economic loss to the nation (GAO 2010: 28).

From a national interest viewpoint the available research suggests the "problem" is rather small and may well involve redistribution from "rights-holders" to consumers rather than any net economic loss. For Australia "problem" appears insignificant.

\subsection{The markets for counterfeits: trademarks and copyright}

The OECD study does not adequately separate the specific legal monopoly privileges which are being undermined through counterfeit and unauthorised use. This limits the capacity to assess fully the extent of any problem and determine proportionate responses. The nature of the issues involved is quite different for counterfeit goods and for unauthorised use of copyright. It is also very different for any parallel problems for other forms of "intellectual property" (discussed in Section 4.2 below).

This is why it is dangerous to use the term "intellectual property". The term "intellectual property" actively impedes rigorous consideration in the issues involved in the infringement of patent and copyright monopolies and trademark registration as each is a quite distinct economic policy with different characteristics and objectives. A major problem with ACTA is the constant use of the term "intellectual property" rather than more specific language. As the purpose of ACTA is to address issues in trademark counterfeits and unauthorised use of copyright it should have been drafted in precisely these terms. It would then be tighter, clearer, easier to assess and less potentially dangerous to Australian economic interests.

Counterfeit goods generally refers to use of a trademark without authorisation for goods in the same line of economic activity as that for which the trademark is registered. As the OECD study identifies there are two markets for counterfeit goods. There is a primary market with high quality close copies where the consumer purchases the product for the normal price believing it to be authentic. This market is quite limited in terms of volume and tends to focus on very high priced goods. Quite different from this is the secondary market where consumers are well aware that they are purchasing a copy. The secondary market is very price sensitive and there is good reason to believe most consumers in this market would not purchase authentic goods as they are beyond their economic reach. Unlike the primary market the secondary market can have considerable volume: indeed it can exceed the size of the primary market (OECD 2008: 48). Data for the US economy suggest that the most substantial proportion of seized counterfeit goods relates to trademark infringement. ${ }^{4}$

Unauthorised copies (referred to throughout the treaty as "pirated copyright products") are copies that infringe copyright, i.e. are made without authorisation.

I do not use the term "pirate" as I consider this indicative of the political agenda of beneficiaries of copyright monopolies. There is evidence that "piracy" - to the extent it exists - flows both ways, with publishers and distributors encrypting material to eliminate fair use of goods, using regional coding so that travellers find that products useless when they get home, and locking (stealing) e-books after purchase should the buyer move countries. Thus throughout this submission I use the less pejorative term "unauthorised copies". Such dispassionate language would be more appropriate for an international treaty and for any reputable study.

\footnotetext{
${ }^{4}$ For 2004-08 58\% of reported seized counterfeit goods were classified as footwear, wearing apparel or handbags/wallets/backpacks (GAO, 2010: 7).
} 
In regard to unauthorised copies there is less evidence here that there is a primary and secondary market. Apart from works of art, it is difficult to imagine what parts of any markets for the unauthorised use of copyright could be primary markets. As indicated above with respect to counterfeit goods, secondary markets rarely compete with primary markets. There is little evidence that consumers in such secondary markets would purchase other than very occasionally in the authorised market. Further there is reason to believe that use of unauthorised copies can operate to the advantage of sellers of copyrighted material. Such shifting from trial in secondary markets to occasional purchase in authorised markets is likely with software, music and books. ${ }^{5}$

In considering appropriate and proportionate responses to unauthorised use of copyright materials the lack of genuine competition between secondary markets and authorised markets is a very important characteristic. In particular this distinction should inform determination of any penalties for infringement.

There are also very substantial differences in the characteristics of markets for physical products and markets for digital products. Much copyrighted material - particularly where unauthorised use is likely (music, software, movies) - is today generally available in digital form. There are many methods of protecting digitised material and the distributors of copyrighted movies and music have been successful in lobbying to achieve legislation to make it illegal to un-encrypt such material. In the case of e-books the distributors readily accept the global provisions of copyright, but then distribute material only on a country-bycountry basis and steal back the goods they have sold by removing access to them should the innocent purchaser move countries. ${ }^{6}$

Most unauthorised use of copyrighted digital material is in the secondary market with prices considerably below those in the authorised market. Industry estimates assume a 1-for-1 substitution rate between the authorised and secondary markets which is clearly wrong. The GAO advises a range of potential positive outcomes for digital copyright holders from unauthorised use including increased brand awareness and shifting between secondary and authorised markets as learning effects increase (GAO 2010: 14-15).

It is difficult to be overly sympathetic to claims for further government assistance to "protect" the distributors of digitised copyright material from competitors where distributors not only take advantage of the copyright system but also use a range of additional "protections" which undermine copyright's balance between consumer and distributor interests. If these parties wish to take advantage of the global provisions for copyright and call on government resources to back up their enforcement efforts, then they should cease using encryption and back repeal of laws making it illegal to seek access to encrypted material. Alternatively where producers use encryption they should not be provided with access to the copyright system, and in particular they should not have free access to government resources to enforce their business model. ${ }^{7}$ It is unfair to consumers for these distributors to have their cake and eat it too.

The constant references in the treaty to "copyright and related rights" presumably derive from the relevant section in the Trade-Related Aspects of Intellectual Property Rights treaty

\footnotetext{
${ }^{5}$ I have myself have purchased a book available as an open access download, because the initial access persuaded me that its value was such that a hard copy for regular reference would be useful.

${ }^{6}$ Private correspondence with amazon.com. This information is not routinely provided to potential purchasers of Kindles.

${ }^{7}$ As far as I am aware the principle of user pays has not yet been applied to recoup the resources expended by Australian taxpayers on enforcing private trademarks and copyright monopolies. Such an initiative might perhaps make a small contribution to meeting Australia's budget challenges.
} 
(TRIPS). TRIPS does not however spell out what these "related rights" are. Nor does ACTA. The phrase "and related rights" is undefined and should be removed from ACTA.

\section{Is ACTA proportionate?}

As indicated above the extent of the problem seems insignificant, and there is no independent evidence that it is growing other than as a consequence of growth in authorised markets. Further there is no sound separation of evidence in respect of trademark counterfeit compared to unauthorised copyright use.

Against this background it is difficult to accept that the proposed range of measures is proportionate to the alleged problem. ACTA calls for the use of even more public resources to enforce private privileges designed to encourage creativity. Most creators find it impossible to distribute their creations without handing over their copyright in perpetuity to distributors. Distributors, for example academic publishers, make very substantial returns from these legislated privileges. Publishers of academic journals have profit levels that economists define as "excess profits" indicating a very substantial return from their copyright monopolies. In 2009 Elsevier's profit rate was 35\% and Reed Elsevier's was 25\%. ${ }^{8}$ There seems no sound reason why "rights-holders" cannot use their own resources to take legal action in any instance of unauthorised use.

There are also reasons to be concerned at the use of criminal sanctions particularly in respect of infringement of copyright. The economic policy of copyright is designed to encourage creativity. It does this by providing the opportunity of a monopoly return to the creator. It restricts what I may do with my own purchased property if the distributor claims copyright privileges. ${ }^{9}$ If the creator's profits are potentially decreased through infringing activity civil remedies, including compensation, are available. Unauthorised use of a legislated power to exclude others from a market is not theft in the way that taking physical property is theft. If my car is stolen I cannot use it. But if one of my publications is used without authorisation nothing is removed from me, particularly if the unauthorised user cannot afford to purchase an authorised copy. The shift from civil to criminal law was an accident of history, taking place in the USA in 1902 following the extension of copyright to the sheet music industry (Boldrin and Levine 2008: 32). At this time, of course, the USA refused to provide full copyright privileges to foreign authors in order to protect their publishing industry. Criminal sanctions for copyright infringement have spread to other countries without any assessment of its impact or proportionality.

ACTA aims to increase the likelihood that holders of copyright privileges, including foreign companies, are able to apply both civil and criminal penalties for commercial scale infringement. ACTA requires criminal penalties for commercial scale infringement, but does not properly define this. It reads:

“... acts carried out on a commercial scale include at least those carried out as

commercial activities for direct or indirect economic or commercial advantage".

ACTA, Article 23(1)

This definition effectively defines commercial as being any activity that provides economic advantage, with no mention of what constitutes scale. If I purchase one unauthorised copy on a secondary market I receive an economic advantage from this and Article 23 as drafted effectively defines this as "commercial scale". Indeed Article 14(1) specifically includes

\footnotetext{
${ }^{8}$ Morrison, 2010. Monbiot (2011) reports Elsevier's profits to have been 36\% in both 1998 and 2010.

${ }^{9}$ Boldrin and Levine, 2008, claim this is the real theft in the intellectual property system.
} 
small consignments in ACTA's ambit. This is another instance of very poor drafting with major implications for the scope of ACTA.

Because the extent of "the problem" has not been properly presented, a full assessment of proportionality is not possible. One notes that the treaty includes frequent use of the phrase "at least ..." suggesting an expansive future. As with the use of the term "intellectual property" this opens the door to wider than intended interpretation, and concomitant dispute.

Proposed remedies are multiple and seem very open-ended and thus potentially disproportionate. Examples include "any legitimate measure of value the right holder submits" (Article 9(1)); "additional damages" (Article 9(3)(c)); and presumptions for determining damages (Article 9(3)(b)). The footnote on this last point provides for damages based on the quantity sold on counterfeit markets "multiplied by the amount of profit per unit of goods which would have been sold by the right holder if there had not been an act of infringement..." (footnote 3, page 7). This is economic nonsense. It is virtually impossible to determine the quantity in the authorised market which might have been sold in the absence of a secondary counterfeit market - the evidence suggests a mere fraction, and there are no sound principles for estimating this fraction in any market. The profit margin in secondary markets is considerably lower than the profit margin in authorised markets. The appropriate presumption would be the quantity sold in the secondary market multiplied by the profit margin in the secondary market which is equal to the profit made from the infringing activity.

The multiple options for providing copyright or trademark holders with compensation when infringing activity takes place do not look proportionate to the nature of any associated harm. In the case of copyright the "rights-holder" is provided by the government with a means of charging high prices to ensure recovery of their investment. In some cases distributors make a substantial profit, in other cases profits can be small. But where the infringement is entirely in the secondary market any concomitant loss to the distributor may be very small. The appropriate recompense in most cases would seem to be the net profits earned from the infringing activity. The actual penalty to the infringer will be greater than this as they will also have wasted all their time and effort.

In the case of counterfeit trademarks, the traditional remedy has been a court order to remove the infringing trademark. For both primary and secondary counterfeit markets there is a case for compensation to take the form of the net profit made by the infringing party. Again this will act as a significant deterrent given the consequent loss of time and resources.

The proposals that equipment used to produce counterfeit or unauthorised products be destroyed do not seem to be limited to knowing use. Without such a limitation such measures seem disproportionate.

ACTA also includes compensation to those innocently charged with counterfeit or unauthorised use. Procedures for ensuring this are required "...not [to] unreasonably deter recourse to these procedures" (Article 18). They should however be sufficiently strong to fully compensate any innocent parties whose business in disrupted by unfounded allegations of infringement.

\section{Some other considerations}

\subsection{Why go it alone?}

As the Productivity Commission noted there are sound economic reasons for preferring multi-lateral trade treaties to bilateral or regional treaties. However, as Drahos has shown, the USA has driven an active agenda of bilaterals and multilaterals as forum shifting allows it 
greater success in achieving an agenda which preferences US business interests (Drahos 2001). The appropriate forums for dealing with the enforcement of agreed "intellectual property" provisions in trade treaties are the World Trade Organisation (WTO), the World Intellectual Property Organisation (WIPO) and Interpol. All have active programs addressing this issue. Further the World Health Organisation (WHO) has an active program addressing the issue of counterfeit medicines (OECD 2008: 185).

Nonetheless the USA has been dissatisfied with progress in achieving the goals of its major corporations in these forums so has pushed forward with ACTA. It is unclear why it has been in Australia's interests to participate in this activity.

Because of the most-favoured nation provisions of TRIPS any "intellectual property" matters agreed in a bilateral or multilateral treaty confer identical benefits on all signatories to TRIPS. This is a poor use of negotiating powers - to negotiate benefits from a small sub-set of nations in exchange for providing benefits to all. This may be less of a problem with ACTA than with the Australia-US Free Trade Agreement (AUSFTA) as the Department of Foreign Affairs and Trade (DFAT) alleges ACTA changes nothing. Which of course begs the question of why they have put so much effort into it (see Appendix 2).

The treaty draft suggests that 37 parties participated in the negotiations. Evidence suggests that it was only 11 parties, with the EU representing its 27 members. There is no evidence of any thorough consideration of these issues within each member nation of the EU. One notes that the Mexican Congress has opposed the treaty although Mexico was a party to the negotiations. ${ }^{10}$ It seems probable that the major influences on the treaty have been business interests acting through the US, EU and Japanese negotiators. These business interests would have been dominated by very large companies owning a significant amount of legislated copyright and patent monopolies and registered trademarks. Some of the odd footnotes in the text, indicating that despite the ambit claim to cover "intellectual property" patents are not covered by particular sections appear to be last minute amendments designed to achieve wider agreement.

While the treaty participants include countries important to Australia's trade interests, Australia has other major trading partners which have actively stood aside from the ACTA negotiations and who are highly critical of it. Examples of critical comment on the ACTA have come from at least India and China. ${ }^{11}$ One has to ask why Australia wishes to offend these other trading partners. Especially if, as implied by the NIA, ACTA merely repeats existing standards.

\subsection{Patents}

The NIA indicates that the primary purpose of this treaty is to reduce "international trade in ... counterfeit trade mark and pirated [sic] copyright products." (para 5). Quite what any secondary purpose is is unclear.

Despite this objective the treaty abounds with the expansionary term "intellectual property" as defined by Part II of TRIPS. ${ }^{12}$ There are frequent references in the treaty to "at least", also

\footnotetext{
${ }^{10}$ Bridges Weekly Trade News Digest, 15:24, 29 June 2011, http://ictsd.org/i/news/bridgesweekly/109704/

${ }^{11} \mathrm{See}$ http://keionline.org/node/1300 and http://keionline.org/node/883 respectively.

12 The proposed treaty defines the catch-all term "intellectual property" in terms of the knowledge monopoly privileges set out in TRIPS Part II. These are patents, copyright, trademarks, industrial designs, circuit layout designs, computer programs, compilations of data, cinematographic works, performers and sound recordings and broadcasts. The TRIPS section on copyright is headed "copyright and related rights" though nowhere in the section are these unspecified "related rights" defined.
} 
suggesting an expansionary intent. While patents are specifically excluded in some footnotes, the treaty should be redrafted to refer only to copyright and trademarks.

Patents have completely different characteristics to copyright and differ again from trademarks. While their term is theoretically more limited, the nature of the monopoly right provided is far stronger - it includes the right to prevent use and sale of independent inventions. This is possibly the first ever treaty proposing to include legislated privileges other than copyright and trademarks in a system of border enforcement measures. This is not noted in the NIA.

A key concern for Australian producers and consumers would be the possible use of the term "intellectual property" to extend ACTA to the patent system, particularly patented pharmaceutical products. Brief consideration is given to this matter here.

The OECD report considers the issue of "counterfeit" patented products. Setting aside problems in defining what is a counterfeit patented product given that most patent infringement involves inadvertent trespass (Bessen and Meurer 2008) and that the determination of whether a patent has been infringed is a complex technical matter, the OECD notes that patented products would be unlikely targets for infringers given the complex equipment needed to produce highly technical and complex products (OECD 2008: 49). The OECD notes that counterfeiting patented products may not involve production but rather re-labelling.

The issues involved in "counterfeit" patented products include:

(i) whether infringement has occurred (hard to determine as patent specifications do not set clear boundaries to what is claimed);

(ii) whether the patent is valid; and

(iii) for some product types whether there are product quality concerns.

It would be a major policy change for Australia to introduce the measures proposed in this treaty with respect to patents. Australia also has good systems for ensuring that marketed products meet health and safety requirements. This is particularly so with respect to pharmaceuticals where the Therapeutic Goods Authority (TGA) must approve manufacturing standards. From a consumer viewpoint the paramount issue with unauthorised pharmaceuticals is quality, and it would be dangerous to prejudice this potentially life and death issue by removing clear and full control from the TGA.

\subsection{Innocent third parties}

From a civil society perspective the Anti-Counterfeiting Trade Agreement (ACTA) was negotiated in considerable secrecy. Why this should be so is unclear and DFAT officials gave no clear answer to questions on this matter in the one "consultation" I attended.

During that "consultation" representatives of shippers and freight forwarders made a number of very telling points in regard to the significant negative impact that the proposed treaty would have on their operations. It is surprising that the NIA does not mention these concerns nor how they have been addressed. Shippers and shipping agents are a vital lubricants in international trade and it is essential that ambit claims from monopoly "rights-holders" not impede genuine trade in real goods and services. ${ }^{13}$ The fact that the agreement might not require new legislation does not mean it will not lead to changes in operational policies that will impact on such parties.

\footnotetext{
${ }^{13}$ As opposed to legislatively created intangibles.
} 
The NIA suggests there was a genuine round of consultations. Consultation is a word implying at least some element of a two-way process. I attended a single consultation and it was far from this. It was a chorus of disparate voices raising a wide range of issues and concerns both for and (more numerous) against the provisions of the draft treaty. The NIA suggests that consultation occurred early. From my own experience working for the government I would suggest that the parties initially consulted were "IP rights-holders", i.e. a one-sided set of the parties affected by copyright, trademarks, patents and other forms of "intellectual property".

I note that the Office of Best Practice Regulation has not required a regulation impact statement. I suggest they may be entirely oblivious to the range of parties who would be affected by this treaty and to the dangers of the expansionary term "intellectual property". At a minimum there should be a detailed analysis of all the parties likely to be affected and whether they will benefit or have new costs imposed on them. This should include Australian consumers - a group not normally consulted by DFAT. This assessment of winners and losers should indicate, at least for major parties, whether they are Australian businesses, Australian-registered subsidiaries of overseas companies, or foreign companies. 


\section{Appendix 1 Issues in measuring counterfeit trade}

Actually measuring the extent of any counterfeiting problem is difficult, as is the case with estimating all illegal activities. The OECD report indicates that despite using a variety of sources the information they gathered falls far short of a robust overall estimate (OECD 2008: 71). While the OECD report is the major source of global estimates for counterfeit trade, it is useful to supplement this with the study of counterfeit markets in the USA published by the GAO. This latter study includes reference to an interesting range of academic studies and also provides clearer detail on the biases in industry estimates of counterfeit products. Most interestingly it discredits three widely-cited estimates of costs of counterfeiting in the USA, indicating that the government agencies to which these estimates are attributed are unable to find the sources for such estimates (GAO 2010: 17-19).

Some industry groups have published estimates of counterfeit trade but their methodologies are rarely clearly spelled out. Some, such as the Business Software Alliance, presume that volumes of goods sold in secondary markets equate with volumes lost in primary markets (GAO 2010: 21), a grossly untenable presumption. Industry lobby group estimates also ignore the benefits to legitimate producers of unauthorised use - in some fields, particularly software, this is considered to be a major means of developing brand loyalty and future upgrade to authorised versions (GAO 2010: 14-15).

The OECD's estimates of counterfeit goods are based on customs seizures. In an effort to include non-traded consumption of counterfeit goods the OECD reviews estimates from consumer surveys in several economies. In the USA in 2004-05 some 14 to $14 \%$ of respondents acquired downloaded products that might have been unauthorised, the main types of goods being music, movies, software and clothing. In the UK in $200534 \%$ advised they had knowingly purchased counterfeit goods (OECD 2008: 74). When considering counterfeit software and digital products, the OECD notes that high levels of use of counterfeit products are found in most developing economies (OECD 2008: 81). This would be consistent with the culture of copying which prevailed before TRIPS and was then an entirely lawful activity, ${ }^{14}$ and with the low income levels in these countries. These high reports of illegal activity indicate the extent to which consumers consider these laws are unbalanced and undeserving of serious attention. They confirm academic analyses that copyright systems have become unbalanced, with continual extensions legislated not in the public interest but because of the power of corporate lobbying.

The OECD study is unusual in that many of the statements are not well-referenced, including the frequent allegations that there is a positive association between "intellectual property" and economic growth. Throughout the study there is a clear "pro-intellectual property" attitude, exemplified for example in the constant use of the loaded word "pirate" for unauthorised use of copyright and flowing through to listing only negative economic impacts on consumers. It is a matter of simple economics that consumers selecting a more reasonably priced product, and happy with its quality are substantially better off than if they are locked out of highprice/high-quality markets. Under impact on innovation the innovative behaviour of copiers is not noted (despite this having been a major growth path in now rich countries and despite it also involving both process and product improvements and variations). Despite these biases the OECD estimates of "the problem" amount, at a maximum, to less than $2 \%$ of world trade.

\footnotetext{
${ }^{14}$ In low income countries it is quite difficult to explain to the low income workers involved in making unauthorized copies of, for example music, why their own government should provide monopolies for foreign parties which prevent them from making an income and fulfilling consumer demand that exists only at that price.
} 
The GAO report is more even-handed in the evidence it presents, noting a range of positive economic effects flowing from markets in counterfeit goods. While major benefits clearly flow to consumers, thus releasing disposable income for expenditure on other goods and services, there can also be benefits to the "rights-holding" companies, including increased brand awareness and future sales.

Both industry groups and US government agencies continue to refer to three major estimates of substantial counterfeit losses in the USA. The GAO approached the agencies allegedly responsible for these estimates and found none could be substantiated. One estimate is sourced to a 2002 FBI press release (losses of US\$200-250b a year) but the FBI has no records of how this estimate was derived and is unable to corroborate the estimate (GAO 2010: 17). A 2002 Customs and Border Protection (CBP) press release has also estimated counterfeit losses at US $\$ 200 \mathrm{~b}$ a year and 780,000 jobs, but the CBP has now advised all staff not to use this estimate and advised the GAO it is of "uncertain origin" (GAO 2010: 18). The Motor and Equipment Manufacturers Association advise an estimate of US $\$ 3 \mathrm{~b}$ a year losses through counterfeit motor vehicle parts, attributed to the Federal Trade Commission (FTC). FTC officials advised the GAO they "were unable to locate any record or source of this estimate within its reports or archives, and officials could not recall the agency ever developing or using this estimate" (GAO 2010: 19).

Both due to the intrinsic difficulties of measuring unlawful activities, and the challenges of providing aggregate estimates when the incidence of counterfeiting appears to vary considerably between product lines, countries and over time, estimates of the size of the problem need to be treated with caution. This is particularly the case where the estimates are provided by interested parties, without clear disclosure of the underlying methodology. From a national interest viewpoint consideration needs to be given to the positive as well as the negative impacts of this counterfeit trade. It should be noted that one major motivator for counterfeit trade is the expectation of high profits. A clear response by "rights-holders" could be to moderate their profit margins, which can be very substantial. This would reduce the incentive for unauthorised use. In the case of digital products one motivation for unauthorised use is to acquire products in formats which can be readily transferred between different equipment (Boldrin and Levine 2008: 35). Again "rights-holders" could reduce the motivation for such unauthorised use by reconsidering their business models and better meeting the needs of their customers. 


\section{Appendix 2 A note on Australia's position on "intellectual property"}

During the Uruguay Round negotiations Australia was a "friend of intellectual property". Quite how this policy position was determined is unclear. As these negotiations began in the $\mathrm{mid} / \mathrm{late}$ 1980s, the IPAC review of the Australian patent system was very recent and should have informed public policy positions (IPAC 1984). That review made it clear that the patent system probably did nothing to increase Australian economic welfare (though there was no clear evidence that it reduced it). As a technology-importing nation, simple back-of-theenvelope calculations show that it would be to Australia's economic advantage to grant legislated copyright and patent monopolies only for limited periods and only for genuinely creative or innovative things. As to trademarks, the negative impact on domestic policy freedom of agreeing to TRIPS is evident in the use of TRIPS by tobacco companies to challenge the Australian government's sovereign right to protect the health of Australians.

Since the WTO package came into force in 1995, the USA has initiated a series of TRIPS+ treaties all of which involve much higher "intellectual property" provisions than agreed in TRIPS. The breadth of this strategy has been demonstrated by Drahos (2001), and from Australia's perspective this culminated in the Australia-US Free Trade Agreement (AUSFTA), which was and remains controversial (see e.g. Dee 2005; Weiss, Thurbon and Mathews 2004). Particular criticism was directed at the "intellectual property" provisions, specifically the unwarranted extension of copyright life, and the provisions bringing Australia's domestic health arrangements (the Pharmaceutical Benefits Scheme) within the ambit of the influence of foreign patent holders.

Australia has followed the lead of the US and has also initiated a series of regional bilateral agreements, most of which follow the template designed by the US to meet US conditions. There appears to have been no realisation that these terms are designed to meet the needs of a very large technology exporting nation. They are inappropriate for a much smaller economy, such as Australia, which is a net technology importing nation producing with a net deficit on the royalties account. ${ }^{15}$

In struggling to understand why Australia ever agreed to sign the AUSFTA, which does not meet the standard of a clear net economic benefit for Australia, one is forced to conclude that non-economic reasons dominate, or that our trade negotiators have a poor grasp of economic reality. It would also appear from the frequent inclusion of matters that do not properly belong in free trade negotiations (as they are designed to limit market competition), that our trade negotiators are poorly informed about the net economic impact of stronger "intellectual property" provisions on the Australian economy. The large majority of patents (in excess of 90\%) and copyrights enforced in Australia belong to offshore entities and the net balance in payments is in favour of overseas countries.

The Productivity Commission's (PC) recent review of Bilateral and Regional Trade Agreements included specific consideration of the inclusion of "intellectual property" provisions in trade treaties, including specific attention to the issue of treaties to strengthen enforcement of such provisions (Productivity Commission 2010: 257-64). The PC noted that most benefits from any enforcement treaty would accrue to third parties not to Australians or Australian entities. It is clear from DFAT's submission on the PC's draft report that DFAT focuses particularly on the interests of those narrow sections of Australian business which

\footnotetext{
${ }^{15}$ While it appears the US insistence on ever-higher "intellectual property" standards provides major inflows of royalty revenue to the USA to offset the deficit on the US current account, no such argument applies with respect to Australia.
} 
benefit from stronger "intellectual property". The Commission rightly took short shrift with this sectional view and referred to its obligations under its Act to consider the benefits and costs to the whole Australian community. It is unfortunate that DFAT does not seem to take such a public interest approach to its trade negotiations. Nonetheless, the Gillard Government agreed with eight of the PC's ten recommendations in full and with the other two in part. ${ }^{16}$

DFAT's pro-"intellectual property" view is also clear from the NIA on ACTA. ${ }^{17}$ They suggest that the alleged problem of counterfeit and unauthorised goods is significant and growing. Yet the OECD analysis suggests that this is probably less than $2 \%$ of world trade, and that growth in counterfeiting is due to greater growth in goods susceptible to counterfeiting rather than to any increase in the propensity to counterfeit. The comment on Australian "intellectual property" holders does not note that the net outflow of royalty payments is substantially larger than copyright foreign exchange earnings. It does not note that the major benefits of this treaty accrue to foreign entities not to Australians. The analysis does not comment on how this proposed treaty fits within the government's response to the Productivity Commission Report. That response agreed that participation in any bilateral or regional trade agreement should only occur on the basis of a demonstrated significant net economic benefit. At no time during the ACTA negotiations, including in the NIA, is there any robust economic analysis demonstrating the winners, losers and net economic benefit. Effectively when it comes to "intellectual property" DFAT seems unaware of the pros and cons of different forms of legislated monopolies and how these intersect with Australia's economic structure.

16 Attachment to Gillard Government Trade Policy Statement, April 2011, available at http://www.dfat.gov.au/publications/trade/trading-our-way-to-more-jobs-and-prosperity.pdf

${ }^{17}$ As noted above I have assumed that the NIA was drafted by DFAT. Authorship is not disclosed. 


\section{References}

Bessen, J.E.and M.J. Meurer, 2008, Patent Failure: How Judges, Bureaucrats, and Lawyers Put Innovators at Risk, Princeton and Oxford: Princeton University Press.

Boldrin, M.and D.K. Levine, 2008, Against Intellectual Monopoly, Cambridge: Cambridge University Press (also at http://www.dklevine.com/general/intellectual/againstfinal.htm).

Dee, P, 2005, "The Australia-US Free Trade Agreement: An Assessment", Canberra: Australia-Japan Research Centre, Australian National University.

Drahos, P., 2001, "BITs and BIPs Bilateralism in Intellectual Property", The Journal of World Intellectual Property 4(6):791-808.

(GAO) United States Government Accountability Office, 2010, Intellectual property: observations on efforts to quantify the economic effects of counterfeit and pirated goods, Washington DC, GAO-10-423 (available at http://www.gao.gov/products/GAO-10-423)

IPAC, 1984, Patents, Innovation and Competition in Australia, Canberra: Industrial Property Advisory Committee (now available at http://www.acip.gov.au/reviews_other.html).

Monbiot, G., 2011, "Academic publishers make Murdoch look like a socialist" in The Guardian, Monday 29 August.

Morrison, H., 2010, "Elsevier 2009 \$2 billion profits could fund worldwide OA at \$1,383 per article" The Imaginary Journal of Poetic Economics, (available at http://poeticeconomics.blogspot.com/2010/04/elsevier-2009-2-billion-profits-could.html)

OECD, 2008, The Economic Impact of Counterfeiting and Piracy, Paris: OECD.

OECD, 2009, Magnitude of Counterfeiting and Piracy of Tangible Products: an update, Paris: OECD.

Productivity Commission, 2010, Bilateral and Regional Trade Agreements - Research Report, (available at http://www.pc.gov.au/projects/study/trade-agreements/report)

Rob, R.and J. Waldfogel, 2006, "Piracy on the High C's: Music Downloading, Sales Displacement, and Social Welfare in a Sample of College Students", Journal of Law and Economics 49(1): 29-62.

Weiss, L., E. Thurbon, and J. Mathews, 2004, How To Kill A Country: Australia's Devastating Trade Deal with the United States. Sydney: Allen \& Unwin. 